Revue interdisciplinaire sur la Grèce archaïque

\title{
Myth, Heritage, Localisation: Atalanta - a Case Study
}

Mythe, patrimoine, lieu : Atalante - une étude de cas

\section{Ken Dowden}

\section{OpenEdition}

\section{Journals}

Electronic version

URL: https://journals.openedition.org/gaia/1899

DOI: 10.4000/gaia.1899

ISSN: 2275-4776

\section{Publisher}

UGA Éditions/Université Grenoble Alpes

\section{Printed version}

ISBN: 978-2-37747-292-5

ISSN: $1287-3349$

\section{Electronic reference}

Ken Dowden, "Myth, Heritage, Localisation: Atalanta - a Case Study", Gaia [Online], 24 | 2021, Online since 31 May 2021, connection on 09 December 2021. URL: http://journals.openedition.org/gaia/1899 ; DOI: https://doi.org/10.4000/gaia.1899

This text was automatically generated on 9 December 2021.

Gaia. Revue interdisciplinaire sur la Grèce archaïque 


\title{
Myth, Heritage, Localisation: Atalanta - a Case Study
}

Mythe, patrimoine, lieu: Atalante - une étude de cas

\author{
Ken Dowden
}
"There are two Atalantas, one from Arcadia, the other from Boiotia." (Scholiast to Theokritos, 3.42)

\section{The problem}

1 Centre and front in Poussin's LaChasse de Méléagre (1634-8; in the Prado) on a resplendent white horse rides, javelin in hand, the maiden Atalanta ready for the fearsome boar. It is a striking painting, but not, maybe, the primary myth for Atalanta -here she is one of a cast of stars. More central for her, if painted on the whole by less famous artists and depicted much less often in antiquity too, ${ }^{1}$ is the myth of her suitor Hippomenes dropping the golden apples in order to outrun her in the race for her hand. ${ }^{2}$ Yet this myth has awkward inconsistencies: does it belong to Boiotia or to Arkadia? Why does her father's name, and that of her suitor, vary? Have different myths, coincidentally attached to a maiden in all cases called "Atalanta", been merged? Yet, as Atalanta is not in any sense a common name and there are significant common features between these manifestations, it looks more as though there has been some sort of splintering of an originally unitary Atalanta. ${ }^{3}$ How then does a mythic figure come to be "splintered"? And what part, and why, does location play in the development of mythology? We have much to learn about mythology from Atalanta.

\section{Myth and history}

2 Myth used to be positioned in the imaginaire by contrast with "legend" and "folktale", either comparand as flawed as the other. "Folktale" (Märchen) carries the baggage of the romantic movement and of post-romantic antiquarianism: though originally 
considered to represent the unmediated expression of the People (Folk), this, as is well known, is largely illusory in the work of the Grimm brothers, who are surprisingly dependent on ultimately literary sources and the tellings of literate friends and relatives. "Legend" is little better, as it depends on the saints' lives from which it sprang to achieve its modern role as a bridge between myth and historical fact. In both of these, one cannot escape the feeling of becoming side-tracked, of arranging exhibits in the museum of the 19th century mind. And neither of these peculiar categories serves to explain or reduce the obstinately distinctive category of myth.

"Myth" is a Greek word, but a modern conception designed for the discussion of Greek culture. ${ }^{4}$ In the case of Greek mythology, though other "mythologies" may have different agendas, the term is used to identify those traditional narratives that concern a past that antedates history. ${ }^{5}$ Greek authors tend to view myths as flawed history, whilst we tend to view them more radically as simply not historical. So for instance, we can consider the myth that Tlepolemos, fleeing the Argolid, colonised Rhodes. ${ }^{6}$ If there actually was a person called Tlepolemos who actually did flee the Argolid and actually did lead a colonising party, in three divisions, to found the Rhodian states, then one may say that for us this would no longer be myth: it would, in fact, be history preserved from, say, the 11th century BC by oral tradition.

In any case, the historical credentials of myth cannot so easily be set aside. As myth by definition has no author, it cannot have been myth when it was first created. This paradox, myth's demand for its own reducibility, would in fact be resolved by the Greek view of myth as distorted history: a telling of (supposedly) real events has evolved into something other, namely what we call "myth". So, Margalit Finkelberg has cast alarming light on a Mycenaean historical stratum in Greek Mythology, by considering the peculiar and distinctive succession patterns of mythic kings as reflecting historical reality. ${ }^{7}$ On the other hand, the Trojan War, whatever realities have led to its siting at Troy, presents an Indo-European tradition of the final war before modern times, one which is seen also, for instance, in the Battle of Kurukșetra in the Sanskrit Mahābhārata. This Indo-European myth corresponds to no reality that is close enough to be discerned and seems in the form in which we have it to be motivated by eschatology.

In a functional sense, myth and history are not so far apart. Both exist in order to assert a past and an identity. For Jan Assmann they constitute "cultural memory" and the purposes of myth and history are in that respect the same. ${ }^{8}$ Each of them after all, as a corpus, constitutes a "reality" with which authors are franchised to engage. "History" itself is a given: authors (genre: "historiography") do not make history, they only tell it, analyse it or explain it, or more rarely discover it. Mythology too is a given, an established intertext ${ }^{9}$ constituted by previous renditions. Authors (genre: "mythography") cannot-at least, overtly or explicitly-create myth any more than they can create history, because, according to a grand romantic idea (a myth in itself), the mythopoeic age is over before our sources begin-it was "a kind of Eocene period". ${ }^{10}$ What authors may do is to rehearse traditions and, in so doing, shift them, change them, introduce variants, favour different players or places. So, for instance, Euripides was bribed (so the story goes) to exculpate the Corinthians of the murder of Medea's children. ${ }^{11}$ But even then the work of authors has no significance without its dialectic with a tradition that already exists.

6 That intertextual tradition resides in the consciousness of participants in Greeknessand those who newly enter Greek culture and lay claim to it will mythologise a link 
between themselves and this tradition, as has been shown by Tanja Scheer and Fritz Graf, ${ }_{12}^{12}$ in order to find inclusion in the intertext. There is no Greekness, and no claim to civilisation, without subscribing to Greek mythology, in the words of Ezio Pellizer, "un vasto sistema culturale, che funziona come un Great Code". ${ }^{13}$

\section{Myth and place}

7 One particular property of myth is fundamental, though it has weakened throughout antiquity and become, except for décor, an irrelevance in the European tradition. This is the property, which it shares with history, of localisation: each Greek myth (with the exception of some recognisable classes, such as the theogonic, purely poetic, or conceptual) belongs to a certain, named, geographical place or landscape in the Greek lands. Indeed, myth like history has a geography. This was first clearly stressed by K. 0 . Müller in 1825 and he deserves still to be read. ${ }^{14}$ Müller maintained that to get at the origins of myth, to isolate almost chemically its distinctive nature, one had to dismantle typically systematising contexts and eliminate discernibly new or poetic developments; then one would find that geography: ${ }^{15}$

It must have been uttered somewhere for the first time. The ascertainment of this where, the localization of the mythus, is of course an essential matter in the business of separating those elements which originally belonged to each other, from those which became afterwards united [...] We have only to ask, Whom does it more immediately concern? Those who dwell in any region speak of their ancient native heroes. The founders of any place are, as such, celebrated in the legends of that place [...].

8 Localisation also underpins the standard ancient organisation of myth, an organisation that starts with a combination of two Hesiodic works, the Theogony, and, more important, the Catalogue of Women. Thenceforward part of the acquis communautaire, the geographically organised system is reflected in subsequent authors down to ps.-Apollodoros' Library. ${ }^{16}$ These proceed genealogy by genealogy, but that is only a way of saying Greek people by Greek people, region by region. It is what Otto Gruppe called "Die Auffassung des Mythos als Stammsage". ${ }^{17}$ After the theogonic material, largely not meaningfully localised, come: the Deukalionids (in Thessaly and neighbouring regions), Inachids (Argolid), Agenorids (Thebes), Pelasgids and Atlantids (Arkadia and Sparta). After that follow more wayward cases, the Elektrids (Troy, a special location-for the most part we are not rehearsing the traditions of the Trojan people), Aiakids (Aigina, Salamis, Phthia, rather tendentious), Kekropids (Athens, a fringe city from the perspective of the mythology), and the Tantalids (effectively the Trojan War from the Greek side-Mycenae, Iliad, Nostoi, Odyssey). ${ }^{18}$

9 This emphasis on localisation of myths passed into the seminal 1854 reference book of Preller, ${ }^{19}$ the Griechische Mythologie, where a significant part of the mythology was similarly arranged into "Landschaftliche Sagen", a region at a time, from Thessaly to Crete. Partly, this results from the organisation of Apollodoros; partly, Preller did in the early 1830 s study under K. O. Müller $(\dagger 1840)^{20}$-and certainly he cites his work. ${ }^{21}$ But Preller also, if through romantic spectacles, saw for himself the close connection of this mythology with the landscape and with the cult of particular places (1854, 2.7-8). And this geographical organisation was taken over, and if anything regarded as underplayed, by Carl Robert in his update of Preller (Preller-Robert, 1920). ${ }^{22}$ Robert interrogated Preller's concept of "Landschaftliche Sagen" and remarked that in fact all 
those myths that underlay the epic tradition had once, in the mists of prehistory ("in grauer Vorzeit", VII), belonged to this category, himself returning to the position of Müller. This is the fundamental point, which Robert was prevented from carrying to its final conclusion by piety to the long dead Preller ( $\uparrow 1861)$ and by his declining health.

It is notable that since Carl Robert, in the many modern approaches to myth, it is the ritualists that have been in the forefront of continuing the respect for locale, due to the need to situate any associated ritual at a particular cult site. ${ }^{23}$ However, I should mention also with respect the more ancient-historical members of the so-called "Paris school", Vernant and Vidal-Naquet. Other, more ideological, approaches to myth find it easier to dispense with this sense of locale. ${ }^{24}$ So, to give one instance, psychoanalytic interpretation is generally locale-free, as can be seen from its successful application also to Märchen/folktale/"fairy tale", often itself distinctly unlocalised. ${ }^{25}$

\section{Myth and mobility: Atalanta}

11 If localisation is key to understanding myth, it is not for that reason organic to any particular myth-there is no reason in principle why it should not be told of somewhere else. Rather, it is the hook that attaches a mythic construct to a particular people or a particular set of ideas. To take an extreme example, the myth of Troy is fundamentally Indo-European: the precursors of the Atreidai and Helen, were IndoEuropean "Dioskouroi"/“Aśvins" and their wife-sister, the daughter of the Sun: these prehistoric mythic characters were assuredly not engaged with Troy. ${ }^{26}$ Rather, the myth became newly sited at Troy and this must be true also of myths that have a more meaningful homeland than Troy. A particular location is not necessarily an original feature of a myth, whatever its importance for myth within a fabric of heritage. Sagenwanderung is as old as Wanderung: if a population moves, the location of its myths will move. ${ }^{27}$ And we need to think about localisation during the early stages of Greek mythology, when heritage was fluid and identities negotiable. Broadly this is the age of the arrival of "Greeks" in Greece and then of their distribution around what became the Greek-speaking lands in the Mycenaean Age. ${ }^{28}$ As the Mycenaean age is constitutive of the mythology, ${ }^{29}$ the population movements at issue are very largely the movements of that age.

12 A useful example is provided by Atalanta, whose story displays an unusual number of variations according to who tells it. If we look at her from the perspective of initiatory theory, what is most central about her is that she is a maiden in a man's world. ${ }^{30}$ Indeed, from the (misleading, as we shall presently see) perspective of the Greek language this is, as Kretschmer argued, what her name means: she is "the same weight (as a man)" ( $\dot{\alpha} \tau \dot{\alpha} \lambda \alpha \nu \tau o \zeta-$ with the copulative $\dot{\alpha}_{-}^{-},=$Sanskrit sa-), an Amazon in a different register. ${ }^{31}$ That is why she mixes with warriors and outruns men-in a bid not to be married. Thus she displays the principal hallmarks of the liminal period, namely reversal and dissociation, and in her case an antithetic, masculine, sense of identity as Ezio Pellizer and J.-P. Vernant showed. ${ }^{32}$ She is a maiden at the threshold of marriage, but, mythically frozen in time, she has not crossed that threshold. Her suitors, like so many other suitors, will all die, except for the one who closes this liminal period and takes her across the threshold. This, then, is the central, unifying core of Atalanta which holds true regardless of variants in the implementation of her myth. 

general sign up ${ }^{33}$ is found in $\Sigma$ Theokritos, III, 42:

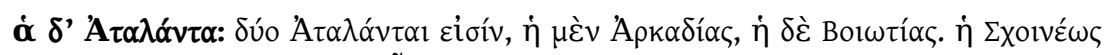

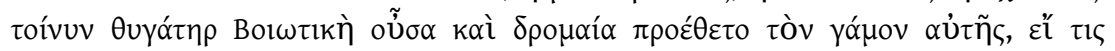

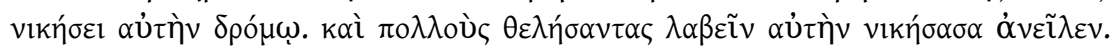

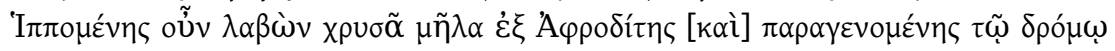

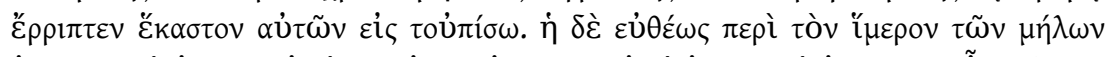

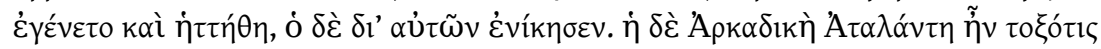
$\delta \varepsilon เ v \eta^{34}$

"And Atalanta": There are two Atalantas, one from Arkadia, the other from Boiotia. So the daughter of Schoineus is a Boiotian and a runner, and proposed that anyone who beat her in a race could marry her. Many wanted to have her but she beat them and killed them. So Hippomenes, getting golden apples from Aphrodite, who attended the race, threw each one of them behind him and (Atalanta) was immediately absorbed in her desire for the apples and was defeated, whereas he won thanks to them. But the Arkadian Atalanta was an awesome archeress.

The same account is given more briefly in $\Sigma$ Apollonios, Argonautika, I, 769-73, which as emended runs: ${ }^{35}$

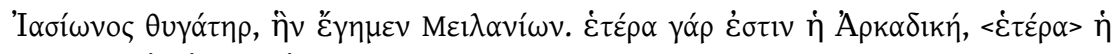

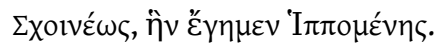

Daughter of Iasion, whom Meilanion married-because the Arkadian (Atalante) is one person, but the daughter of Schoineus, whom Hippomenes married, another.

15 Coincidence between these scholia might most naturally point to Theon of Alexandria (of the Augustan era) as the original author. ${ }^{36}$ The second scholion proceeds to explain the mountain name Mainalos (where Atalanta spends her time) on the basis of Hellanikos and there is accordingly the possibility, though no more than this, that the account of Atalanta altogether is that of Hellanikos (BNJ $4 \mathrm{~F}$ 162).

We have, then, according to this account two Atalantas. I now present the dossier on both, and briefly on a third, using the following shorthand:

"Theon" = $\Sigma$ Theokritos, III, 42 and $\Sigma$ Apollonios, Argonautika, I, 769-73.

Hesiod = Hesiod, Catalogue of Women (fragments as numbered by Most, 2007).

Ovid = Ovid, Metamorphoses.

\subsection{Atalanta the Boiotian}

- This Atalanta is the daughter of Schoineus: Hesiod (F 48, 12; F 48, 34; F 51); "Theon"; Ovid, Metamorphosis, X, 609; Hyginus, 185.

- Her suitor in the running race is Hippomenes: Hesiod (F 50); Euripides ${ }^{37}$ according to Apollodoros, III, 9, 2; Theokritos, III, 40-42; “Theon"; Ovid, Metamorphosis, X, 560, 575; Hyginus, 185.

Only "Theon" makes it explicit that we are dealing with a myth set in Boiotia. The name Schoineus, however, tells us that her father is "(man) of Schoinos", apparently the place in Boiotia (Iliad, II, 497 and $\Sigma$ ) that Strabo (IX, 2,22) tells us is a $\chi \omega ́ p \alpha$ in the territory of Thebes, 50 stades from Thebes itself and with a river, "Schoinos" or "Schoineus", ${ }^{38}$ running through it. ${ }^{39}$ The name recurs elsewhere in Greece, at the Isthmus where the diolkos ends (Strabo, VIII, 6, 22), and near Knidos too. We shall also 
presently see an instance in Arkadia. As oxoĩvo denotes reeds and rushes, it is a suitable placename for marshy ground.

The running race is a mythic version of, to use the Sanskrit term for what is quite conceivably an Indo-European custom, a svayamvara, a contest for the hand of the bride, nominally chosen by the bride herself, though in fact managed by the father. In this respect it is quite like the story of Pelops, situated at Elis, though the myth of the Danaids can also conclude with a foot-race. ${ }^{40}$ It also fits well with the transmission of royal power from one eligible family to another that Finkelberg has reconstructed from the mythology, implicitly for Mycenaean history. ${ }^{41}$

In addition, the myth has a clear initiatory typology, slotting neatly into phases $\mathrm{b}$ and $\mathrm{c}$ of Ezio Pellizer's 1986 "peripezia" structure ("iniziazione", “matrimonio"):42

1. Atalanta is at the age for marriage (cf. Iphigeneia, Proitids, Danaids).

2. She rejects marriage (Kallisto, Danaids). ${ }^{43}$

3. She is conspired against by a goddess (Kallisto, Io, Proitids).

4. She engages in a running race (arkteia, Danaids).

5. The story ends with her marriage (Proitids, Danaids).

6. Unless the wrath of the goddess continues (Hyginus, 185; cf. Melanippos and

Komaitho at Patrai ${ }^{44}$ ).

Her profile may be somewhat closer to other Peloponnesian myths than to that of Iphigeneia.

The svayamvara is typically a special and royal/princely event. It demands the reduction of any initiate group to a single notable individual. ${ }^{45}$ Atalanta is not just a miscellaneous Boiotian but an important figure by genealogy. Her father Schoineus is a son of Athamas ("Theon", Apollodoros, and evidently Hesiod), one of the five sons of Aiolos (Hesiod, F 10, 25-26; Apollodoros, I, 7, 2). Where Aiolos, eponym of the Aiolian Greeks, had ruled over Thessaly (Apollodoros, I, 7, 2), Athamas, suggestively in the next generation, rules over Boiotia (Apollodoros, I, 9, 1). ${ }^{46} \mathrm{~A}$ historical southward movement of the Aiolian Greeks seems charted here, belonging to the times early in the second millennium BC when the Greeks first entered mainland Greece. Atalanta, then, is Athamas' granddaughter, and the great-granddaughter of Aiolos himself.

\subsection{Atalanta the Arkadian}

- This second Atalanta is the daughter of Iasion according to "Theon"; or of $\operatorname{Iasos}^{47}$ (a son of Lykourgos, and descendant of Arkas) and Klymene (a daughter of Minyas) according to Apollodoros, III, 9, 2. The same passage misleadingly reports Euripides as saying her father was Mainalos, mistaking a statement of geography for one of paternity. ${ }^{48}$

- She is a formidable huntress, originally suckled by a bear, who strenuously maintains her

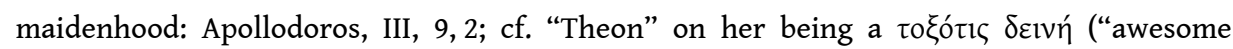
archeress").

- She spends her time hunting on Mt Mainalos: Apollonius Rhodius, I, 770; "Theon" = $\Sigma$ Apollonius Rhodius, I, 769; cf. Maenalia Atalanta (Ovid, Heroides, IV, 99).

- Her suitor is M(e)ilanion (or Mel-): "Theon"; Apollodoros, III, 9, 2;49 Hellanikos BNJ 4 F 99 (= $\Sigma$ Euripides, Phoinissai, 150).

In addition, Pacuvius wrote a tragedy, the Atalanta, whose remains make clear that it is based on the Arkadian one. And Accius wrote a Meleager, including the presumably Arkadian Atalanta, probably following the lost Meleager of Euripides. ${ }^{50}$ 

The scholiast interprets it as a deliberate mis-telling, and some moderns agree; ${ }^{56}$ however, it is considered by Robert (Preller-Robert, 1920, 94) to be a very old version of the story. Here, Melanion is a youth who flees marriage and lives in the mountains, hunting hares with his dog, thus arousing the hatred of the womenfolk. It is indeed odd for a youth rather than a girl to be fleeing marriage, though Hippolytos might offer a comparand, and maybe Orpheus and Pentheus if the story had culminated, as it seems to demand, in the death of Melanion at the women's hands. Aktaion too might not be far distant from this myth, and rituals of theoretically murderous chasing of one sex by another might lurk in the background.$^{57}$ On this view, the myth of Melanion would have been merged into the Atalanta myth in order to bring it closer to the expected (Boiotian Atalanta) pattern. It also generates a fashionably Hellenistic boy and girl story such as might appeal to an Ovid. Certainly Robert supposed an Alexandrian poem, one whose influence had been traced in detail by Ernst Maass. ${ }^{58}$ It evidently gave an impetus to an Arkadian Atalanta story with Melanion and no running race. It would still, however, leave open the question of what Atalanta's story was before that poem other than that she "hunted on the mountain". Perhaps there was a primal boar hunt (see below) in which she killed the boar. Or maybe her feat was to kill the Centaurs Hylaios and Rhoikos. ${ }^{59}$

urning to localisation, this Atalanta spends her time on Mt Mainalos, which is a western boundary of the land of Tegea and of Mantinea. The whole area is rather a heritage landscape. Pausanias' Schoinous and running-track of Atalanta are somewhere on or beside the next mountain west of Mainalos, Mt Phalanthos, and somewhere in the plain before you reach it is the Tomb of Kallisto in a shrine of Artemis Kalliste (Pausanias, VIII, 35, 8-9). A similar cultural inventiveness underlies Scopas' decoration (c. $390 \mathrm{BC}$ ) of the main pediment of the temple of Athena Alea at Tegea with the 
Kalydonian boar hunt, including of course Atalanta (Pausanias, VIII, 45, 4-7). This temple also contained the tusks of the boar until Augustus stole them (VIII, 46, 1), and it still contained the severely decayed hide of the animal (VIII, 47,2). The sanctity of relics is paralleled by the Spartan removal from Tegea of the Bones of Orestes in the mid-6th century BC (Herodotos, I, 67-68), ${ }^{60}$ perhaps helped by the placename Oresthasion, SW of Tegea, almost at (the later) Megalopolis (e.g. Pausanias, VIII, 39, 4; $44,2)$, as well as by the tradition of his withdrawal from the Argolid to Arkadia (Pausanias, VIII, 5, 4).

Though we see here some cultural accretions, there must have been something for them to accrete around: the name Atalanta looks like the magnet that attracts mythology attached to other instances of the name; Mainalos could indeed be the right location for an Atalanta; her hunting seems to be the designated activity of a figure belonging in the initiatory wild; and her genealogy may have something to tell us. On the other hand, we can identify some adventitious elements: the inconsistent father "Schoineus" who names a place "Schoinous"; obviously the racetrack (e.g. because of its pedestrian nomenclature, "the Racetrack of Atalanta"); the physical relics of the Kalydonian boar hunt; and probably the connection with the Kalydonian boar hunt at all (see below).

Arkadian Atalanta is, like Boiotian Atalanta, a figure with an initiatory profile:

1. She is at the age for marriage.

2. She rejects marriage.

3. She lives in marginal lands, on a mountain.

4. She engages in hunting, an inversion of expected female behaviour characteristic

of the liminal period.

5. The story ends with her marriage.

The hunting profile suggests she ought to belong to a cult of Artemis (for whom she is something of an avatar). ${ }^{61}$ Robert (Preller-Robert, 1920, 93 and n. 6) may therefore have been right to take seriously associations of her with Artemis that start in our record with Euripides, Phoinissai, 152.

She also has no less significant a genealogy, though it is hard at this distance to fathom its dynamics. It is of some importance that her father is Iasos, or Iasios or Iasion, which makes her the "Iasian maid" ( $\alpha \propto \rho \theta \varepsilon$ vov 'I $\alpha \sigma i n v)$, or maybe, conversely, her being the "Iasian maid" makes him Ias(i)os/n.62 The same name is given for the father of Io by Apollodoros as though it were standard, and it is accepted by Pausanias. ${ }^{63}$ The Ias- name may once have had some ethnic/geographic importance, as it seems to in the notorious reference of Eurymachos in the Odyssey to "I $\alpha \sigma 0 v$ 'Apyos (where hypothetically there might be Axoı 10 to admire Penelope, Odyssey, XVIII, 246), ${ }^{64}$ given that Argos can also be Pelasgic or actually Achaian. ${ }^{65}$ There is usually thought to be no connection between Iăson (Argos) and Iāon-, an earlier form of the name for "Ionian", on the grounds that the $-a$ - is short in the former and long in the latter. ${ }^{66}$ This objection falls if the words were seen as combining a root $I-$ with endings $-\breve{a s o s}$ and $-\bar{a}(w) \bar{o}$, to which one might add the feminine adjective I-ad- ("Ionian"). Such a root has been persuasively argued by Nikolaev, in the view that most Greek tribal names can be interpreted from Greek. In this case Nikolaev supposes the Indo-European root to be *uiH- "might" (Latin vis), as found in the Homeric $\tilde{i} \varphi 1 .{ }^{67}$ Other names in myth that may contain this ethnic root include Iōlkos (I $\omega \lambda_{\kappa o ́} \varsigma$ or 'I $\alpha \circ \lambda_{\kappa o ́}$ ), long ago analysed as Iawo-holkos, "Ionian (boat-)slipway" ${ }^{68}$ So far as our evidence goes, it is in plainly Aiolic territory, but the bay of Pagasai does face (Ionic) Euboia and so it might be possible to hypothesise Ionian 
occupation at some early, foundational, stage. Indeed, Kretschmer argued for a much wider occupation of Greece by "Ionians" before the arrival of the "Achaioi" (i.e. "Aiolians"). ${ }^{69}$ Another possibility is Iole (Ió $\lambda$ ), the maiden of Oichalia, the daughter of its king Eurytos, seized by Herakles and married to his son Hyllos. There was an Oichalia in Euboia and that is where Sophocles places Oichalia in the Trachiniai $(74 ; 401)$. And a final name to add to this cluster is of course Io herself, $I-O$, in effect "the Iasian maid" like Atalanta.

Whatever the exact remit of this parentage, Arkadian Atalanta is clearly at a high level in the genealogy and this is made clearer on the maternal side by the fact that her mother Klymene is a daughter of Minyas. Minyas in turn is the eponym of the Minyai, a tribe which had lost most of its significance by the historic age, ${ }^{70}$ but which was indissolubly associated with "Minyan" Orchomenos in Boiotia. The Minyai are also closely associated with the Argonauts, whose leader is Jason (I-āson-, then) and who set out from Iolkos (see above). Fowler remarks that "the Minyans seem at one time to have extended from south Thessaly to Lake Kopais" and shows how not only is this the "heartland of the Aiolians" but that mythography as a whole seems to be trying to associate them with the Aiolians. Certainly "they found no independent place in the Hellenic tree". ${ }^{71}$

Thus the Arkadian Atalanta is connected by genealogy to the population of Boiotia, and the particular town-name Orchomenos also recurs in the Arkadian landscape. Mantineia is about $20 \mathrm{~km}$ north of Tegea, and Arkadian Orchomenos about $15 \mathrm{~km}$ further north again; west of all three lies Mt Mainalos. ${ }^{72}$ I hypothesised in Death and the Maiden that the Minyans were responsible for the various Orchomenoses, retracing the steps of K. O. Müller. ${ }^{73}$

The Arkadian Orchomenos was a place of considerable significance down to the late 7th century BC..$^{74}$ Till then it was ruled by kings, the last being Aristokrates (and possibly his son Aristodemos), ruling over a large part of Arkadia. ${ }^{75}$ Thus Orchomenos was the leading city of the area including Mantineia and Tegea, and bordered by Mt Mainalos in the West, with the consequence that the Arkadian Atalanta story, with its Mainalos setting and Tegean pretentions, should be regarded as part of the heritage of Orchomenos.

\subsection{Atalanta and the Kalydonian Boar}

As early as the mid-6th century BC François vase (LIMC Atalante 2), perhaps in the wake of Stesichoros' Suothēra, ${ }^{76}$ Atalanta, and also Melanion, her Arkadian suitor, are participants in the Kalydonian Boar Hunt..$^{77}$ Given the strict significance of localisation for myth (see $\$ 3$ above), this is impossible. Atalanta cannot be the heroine of a story of Arkadia-perhaps Tegea-and at the same time perform in a myth whose stakeholders are at Kalydon. Real persons may travel; mythical persons cannot, except for reasons of ideology, for instance to denote movement to a margin (like Theseus in Crete or the Danaids in Egypt). However, poets may combine stories differently localised into a bigger or more systematic whole..$^{78}$ One particular type of combination is to create a supermyth, useful for competitive poets. So, Herakles develops a biography of labours; a major war, at Troy or Thebes, may assemble a cast of stars; the ship Argo, disseminating colonial mythology as it goes, may collect familiar faces for the great feat (even including Atalanta), ${ }^{79}$ whilst disposing of Herakles and Hylas when they no longer 
serve any purpose. Not without reason does Hyginus devote sections to: Qui ad aprum Calydonium ierunt (173), Qui ad Troiam et quot navibus ierunt (97) and Argonautae convocati (14). The François vase is the visual reflection of such a combinatory catalogue, and Vidal-Naquet rightly spoke of "une chasse où sont rassemblés les héros de la Grèce". ${ }^{80}$

35 Assuming this is the case, it follows that either the famous huntress (therefore Arkadian) Atalanta and her opposite number Melanion have been poetically imported to do hunting at Kalydon, or, as Robert once supposed ${ }^{81}$ there had originally been a different boar-hunt myth located in Arkadia. But if there was such a myth in Arkadia, then the first strike at the boar and the reward of the boar's hide might well have been Atalanta's and perhaps too the hide displayed in the temple of Athena Alea in Tegea was in origin that hide and not the Calydonian one. Conversely, if Melanion and Atalanta are both hunting in the Arkadian landscape, then perhaps the Kalydonian hunt began from a very similar kernel. There could originally have been a third ${ }^{82}$ Atalanta and her admirer Mel-eager may then be a functional equivalent of Mel-anion.

\section{Divergence and convergence}

If we consider first the Boiotian and the Arkadian Atalanta, it is clearly unsatisfactory to represent them as two different stories that coincidentally refer to someone called "Atalanta". Atalanta functions as a marginal maiden, confronting and rejecting the prospect of marriage. The moment of transition is dramatised, but it is the same moment and the same name and surely in origin the same mythic figure. That sameness is felt even in later (post-Mycenaean) ages as the Boiotian instance contaminates the Arkadian and as the Arkadian is made to travel to take part in the Kalydonian event (perhaps contaminating a Kalydonian Atalanta story).

Atalanta is also genealogically fundamental for the stakeholder population of each myth. As a Boiotian, she is granddaughter of Athamas son of Aiolos. Athamas rules, it seems, over ethne rather than cities, though he can be king of Orchomenos. As an Arkadian, she is granddaughter of Minyas. It is not impossible, as West suggested, that the Hesiodic Catalogue saw Minyas as another son of Aiolos, ${ }^{83}$ in which case another coincidence would be added-that both Atalantas are great-granddaughters of Aiolos. ${ }^{84}$ The surprising inclusion of Minyas in the Arkadian version, links it with Boiotia, as we have seen, as more broadly does the name and role of Orchomenos in both landscapes. Orchomenos, like Atlanta, is a transplanted name and the ruling centre where her name is current.

Atalantas bear comparison with the Iphi- figures whose distribution lies in a different area, to the east of the Atalantas. ${ }^{85}$ At Sikyon Iphinoe is worshipped; she also finds a place in myth from Tiryns. Iphigeneia, commemorated at Megara, is worshipped at Brauron, and belongs to myth from Aulis. Like Atalanta, these have diversified in different locations, but not so far that they cannot later be confused and contaminated with each other. They can all be king's daughters, suspended at the age at which marriage comes next. And to this group also belong Io and Kallisto, as well as the Danaids of the Danaoi.

Overall, we may say that the Greek peoples of Mycenaean Greece, from whom the mythology descends, from the beginning reflected in their mythology the importance 
they assigned to the transition from girlhood to married womanhood. They generated or regenerated a number of figures to encapsulate this moment, different in different places, but to serve a very similar function. In the different forms we see some insistence on national (and royal) identity, going back to the beginnings of the particular Greek group to which they perceived themselves as belonging.

As peoples move, there takes place what earlier scholarship called Sagenwanderung. ${ }^{86}$ This is still what I have called, borrowing the term of Max Müller, the mythopoeic stage. In reference to one of Ezio Pellizer's more ingenious pieces, one might say that there is a sort of "confusion of myths" as they depart their "Tower of Babel", and new pressures drive them apart. ${ }^{87}$ Thus the Minyans of Boiotian Orchomenos took with them their Atalanta to their new Orchomenos in Arkadia and a new Atalanta took shape; and maybe at Kalydon "Aitolians" identified with this group. Meanwhile to the East, there was a different culture in which Iphigeneia and her Iphi- sisters emerge from Aulis down to Tiryns. And at the "Argive" Heraion, the figure is more simply I-o. If, as we have seen Nikolaev suggest, the I- root is tribally significant and comes from the old word meaning "might/strength", then we may regard these easterners as identifying themselves as I- people, as embryonic "Ionians"-the word that also gave the generic term for Greeks to Eastern foreigners (e.g. Akkadian yawan, Hebrew jwn). ${ }^{88}$ In this context it is interesting that Rodriguez Adrados surmises, purely looking at how Greek dialect groups began to take shape in the late Mycenaean period, "that there was a linguistic territory with common characteristics that extended from Attica to the Peloponnesus by way of the Corinthian Isthmus". ${ }^{89}$

41 Nor should the different populations of mainland Greece be thought to be uninfluenced by each other. The "Iasian maid" Atalanta is by that genealogy and description made relevant to the eastern group and represents in effect a link between, say, Arkadia and Argos. It would not be the only one. ${ }^{90}$ And when populations migrated to form the colonies that made Ionia, it was not exclusively of Ionians: among them, according to Herodotos, were the Minyai of (Boiotian) Orchomenos. ${ }^{91}$ They are not associated with the Aiolian colonies, and it may be that Fowler is right to question the attempts of genealogy to connect them to Aiolos at all..$^{92}$ After all, if they are rightly associated with the myth of Argo, the etymology of its port, Iolkos, as we have seen, may suggest Ionians. The place therefore of these Minyai may be between these two big groupings. The mythology is far from definite, but it is making historical suggestions.

So what we are dealing with here is the maintenance of tradition, heritage, genealogy and, in short, identity among populations. Just as the speakers of the Indo-European languages came to differentiate their (Sanskrit) Dyāuh from (Greek) Zeus and (ProtoGermanic) *Tiwaz in order to match their new cultures in their new locations, so in the case of Atalanta too, the mythology is retained as a matter of national identity but is adjusted and reconfigured.

After this, localisation progressively loses its force. The poetic tradition, working "internationally", establishes mechanisms for uniting and combining the disparate mythology. Local traditions are assigned a place in Greek Mythology, whether genealogical or in a super-myth. It is remarkable that Atalanta turns up as a duplicate in this system.

Later still, in the Hellenistic age, local autonomy has so diminished that localised myth declines into "heritage" in our modern sense, as when Pausanias is shown the running track of Atalanta. It then remains for Romans and Europeans, taking their cue from 
Ovid, to lose interest in, or knowledge of, Greek local geography. They know as little about Boiotia as soon they will know about Canaan. The myth is valuable now for its aesthetics and for the ideas it stimulates or is felt to encapsulate. That is an interesting history too, but locale and patrimony has been lost, though the intertext that is Greek Mythology endures and is shared by evolving audiences, perhaps enjoying opera or fine art.

\section{Traces of pre-Greek mythology?} It is worth inspecting the phonetic shape of talanton, and of Atalanta. The syllables are generally open ${ }^{95}$ and a vocalism with A persists except for a Greek ending (-on). It is the same for her ancestor Athamas (gen. Athamantos), king at Minyan Orchomenos, who also has the -nt- suffix. The same set of vowels and consonants can be used to make Tantalos (with his Lydian connections). ${ }^{96}$ This appears to be a pre-Greek set of parts, with some Anatolian characteristics. One cannot reasonably go further in the present paper, but this does invite thoughts about substratum, population mixture, and whether the Minyai were in origin Greek at all.

49 The names of Atalanta's partners, too, seem to ring changes on a limited set of phonemes: Hippo-MENes; MELaNion; MELeagros. And there are two other names which might belong to such a group: MENeLaos, who must have won Helen herself, and MaiNaLos, her Arkadian mountain. The vowel E is very useful for giving the appearance that Greek words are at issue, but it may be that the (initiatory!) connection with "black" (melan-) and that with "might/staying power" (mene-) are further instances of folk etymology, of re-etymologising an inherited word. 


\section{Conclusion}

Greek mythology has a history and a geography. Some myths, such as that of the "Trojan" War go back long before there were Greeks, but others are more tightly tied to Greek locations. The Atalanta myth shows us through its variants that locations can under certain circumstances multiply. Given that the location in these cases expresses, in some sense, ownership of the myth, it follows that the multiplication of locations ("splintering") reflects population movement, or divergence, whilst preserving heritage and core values. One of those core values is embedded in the life course of women, where myths in particular encompass the transition from maidenhood to womanhood, an "initiation" that helps form adult identity. This is where Atalanta belongs. The population movements in question are those of the formative age for Greek mythology, the "mythopoeic" age, namely the second millennium BC. The traces may be faint, but we can see how the recurrence of the Orchomenos placename in Boiotia and Arkadia mirrors that of Atalanta. The populations involved do not respond to a simple Mycenaean v. NW Greek/Dorian division; indeed, the second group is irrelevant. What we are in fact seeing are different strata in the "Mycenaean" mix in mainland Greece, which bear some relation to the dialect map of historic times. ${ }^{97}$ The ancestors of what we would later call Aiolian peoples must have been predominant in Late Mycenaean Boiotia-but not to the exclusion of all others. To the East of them, and in Euboia, in later times there were Ionians and it may be that their ancestors were the first entrants to Greece before in many places being overlaid by the "Aiolians". Somewhere between them were the Minyans and we have seen some mythic reason to suppose that they belonged more with the Ionians than with the Aiolians, even down to the mythic father of Arkadian Atalanta, "Iasos", whose parenthood may have been an important point as homes shifted to a new world in Arkadia. Atalanta in that sense seems to be registered as a Minyan figure. But when we probe deeper we find a different population altogether, one that does not seem, from her name, to be Greekspeaking. Somewhere in northern Greece, and before the movement to the Peloponnese, maybe even before the "descent" into Boiotia, her name had been formed and possibly that of her partner too.

51 Thus Atalanta provides an intriguing case that casts light, some strong, some faint, on the formation of the Greek mythology we have and on the history that underpinned it. It is for us to detect the gravitational waves.

\section{BIBLIOGRAPHY}

ALLEN Thomas W., “Argos in Homer”, CQ, 3, 1909, pp. 81-98.

ARRIGONI Giampiera, Atalanta e le altre: scritti editi e inediti, Bergamo, Sestante, 2019.

ASSMANN Jan, Das kulturelle Gedächtnis, München, Beck, 1992.

Gaia, 24 | 2021 
BARRINGER Judith M., “Atalanta as Model: The Hunter and the Hunted”, CA, 15, 1996, pp. 48-76. BAUMEISTER Karl August, s.v. Preller, Ludwig P., in Allgemeine Deutsche Biographie, 26, Leipzig, 1888, pp. 561-6.

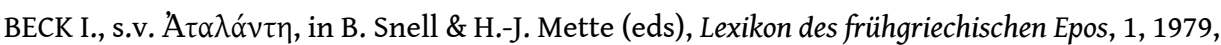
pp. 1470-1.

BEEKES Robert S. P., Etymological Dictionary of Greek, 2 vols, Leiden, Brill, 2010.

BETTELHEIM Bruno, The Uses of Enchantment: The Meaning and Importance of Fairy Tales, London, Thames and Hudson, 1976.

BOARDMAN John \& ARRIGONI Giampiera, “Atalante”, LIMC 2.1, Zürich, Artemis, 1984, pp. 940-50. BOISACQ Émile, Dictionnaire étymologique de la langue grecque, étudiée dans ses rapports avec les autres langues indo-européennes, Heidelberg, Winter \& Paris, Klincksieck, 1916.

BRULÉ Pierre, La Fille d'Athènes, Paris, Belles Lettres, 1987.

BURKERT Walter, The Orientalizing Revolution, Eng. tr., Cambridge (MA), Harvard University Press, 1992.

BUXTON Richard, “The Significance (or Insignificance) of Blackness in Mythological Names”, in J. Dijkstra, J. Kroesen \& Y. Kuiper (eds), Myths, Martyrs, and Modernity: Studies in the History of Religions in Honour of Jan N. Bremmer, Leiden, Brill, 2010, pp. 31-43.

CHANTRAINE Pierre, Dictionnaire étymologique de la langue grecque : histoire des mots, 2 vols, Paris, Klincksieck, 1968.

COLLARD Christopher \& CROPP Martin, Euripides: Fragments, vol. 1, Cambridge (MA), Harvard University Press, Loeb Classical Library, 2008.

DOWDEN Ken, Death and the Maiden: Girls' Initiation Rites in Greek Mythology, London, Routledge, 1989.

DOWDEN Ken, Uses of Greek Mythology, London, Routledge, 1992.

DOWDEN Ken \& LIVINGSTONE Niall, A Companion to Greek Mythology, Oxford / Malden (MA), Blackwell, 2011.

FARAONE Christopher A., “Aphrodite's KEETO and Apples for Atalanta: Aphrodisiacs in Early Greek Myth and Ritual”, Phoenix, 44, 1990, pp. 219-43.

FINKELBERG Margalit, Greeks and Pre-Greeks: Aegean Prehistory and Greek Heroic Tradition, Cambridge, Cambridge University Press, 2005.

FONTENROSE Joseph E., Orion: The Myth of the Hunter and the Huntress, Berkeley / Los Angeles / London, University of California Press, 1981.

FOWLER Robert L., Early Greek Mythography, vol. 2: Commentary, Oxford, Oxford University Press, 2013.

FRISK Hjalmar, Griechisches etymologisches Wörterbuch, vol. 1, Heidelberg, Winter, 1960.

GANTZ Timothy, Early Greek Myth: A Guide to Literary and Artistic Sources, Baltimore (MD), Johns Hopkins University Press, 1993.

GERHARD F. W. Eduard, Griechische Mythologie, 2 vols, Berlin, Reimer, 1855.

GRAF Fritz, Nordionische Kulte: religionsgeschichtliche und epigraphische Untersuchungen zu den Kulten von Chios, Erythrai, Klazomenai und Phokaia, Roma, Schweizerisches Institut in Rom, 1985. 
GRUPPE Otto, Geschichte der klassischen Mythologie und Religionsgeschichte während des Mittelalters im Abendland und während der Neuzeit, Leipzig, Teubner, 1921.

HUNGER Herbert, Lexikon der griechischen und römischen Mythologie ${ }^{8}$, Wien, Hollinek, 1988.

HUYS Marc, “Euripides and the 'Tales from Euripides”, RhM, 140, 1997, pp. 308-27.

IMMERWAHR Walter, Die Kulte und Mythen Arkadiens, vol. 1, Leipzig, Teubner, 1891.

KANNICHT Richard, Tragicorum Graecorum Fragmenta, vol. 5: Euripides, Göttingen, Vandenhoeck und Ruprecht, 2004.

KRETSCHMER Paul, Einleitung in die Geschichte der griechischen Sprache, Göttingen, Vandenhoeck und Ruprecht, 1896.

KRETSCHMER Paul, “Zur Geschichte der griechischen Dialekte”, Glotta, 1, 1909, pp. 9-59.

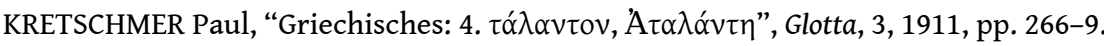

KUHNERT Ernst, "Meleagros”, in Wilhelm H. Roscher (ed.), Ausführliches Lexikon der griechischen und römischen Mythologie, vol. 2.2, Leipzig, Teubner, 1894, coll. 2591-622.

LEAHY D. M., “The Bones of Tisamenus”, Historia, 4, 1955, pp. 26-38.

LIMC = Lexicon Iconographicum Mythologiae Classicae, Zürich / München, Artemis Verlag, 1981-1999.

MAASS Ernst, “Alexandrinische Fragmente”, Hermes, 24, 1889, pp. 520-9.

MALKIN Irad, A Small Greek World: Networks in the Ancient Mediterranean, New York / Oxford, Oxford University Press, 2011.

MAX MÜLLER Friedrich, “Comparative Mythology”, in Oxford Essays contributed by Members of the University, London, John W. Parker, 1856, pp. 1-87.

MEYER E., “Orchomenos (4)”, RE, 18 (1), 1939, pp. 887-905.

MOST Glenn W., Hesiod: The Shield, Catalogue of Women, Other Fragments, Cambridge (MA), Loeb Classical Library, 2007.

MÜLLER K. Otfried, Prolegomena zu einer wissenschaftlichen Mythologie, Göttingen, Vandenhoeck und Ruprecht, 1825; English translation: Introduction to a Scientific System of Mythology, London, Longman, Green, Brown and Longmans, 1844.

MÜLLER K. Otfried, Geschichten hellenischer Stämme und Städte, vol. 1: Orchomenos und die Minyer ${ }^{2}$, Friedrich W. Schneidewin (ed.), Breslau, Rar, 1844.

NIKOLAEV Alexander S., “'Ióoveৎ”, Acta Linguistica Petropolitana, 2 (1), 2006, pp. 100-15.

NILSSON Martin P., The Mycenaean Origin of Greek Mythology, Berkeley / Los Angeles, University of California Press, 1932.

PELLIZER Ezio, Favole d'identità, Favole di paura, Roma, Istituto della Enciclopedia Italiana, 1982.

PELLIZER Ezio, “La peripezia dell'eletto. Strutture del racconto e biografie eroiche”, Ítaca: Quaderns Catalans de Cultura Clàssica, 2, 1986, pp. 43-53.

PELLIZER Ezio, “Migració i polisèmia dels mites. L'exemple de Babel”, in J. Malé i Pegueroles (ed.), Del mite als mites, Santa Coloma de Queralt, Obrador, 2007, pp. 25-48.

PELLIZER Ezio, “L'initiation ratée. Retour au Chasseur noir”, Gaia, 14, 2011, pp. 157-69.

PELLIZER Ezio, “Introduzione: Ulisse tra mito, simbolo e immaginario", in E. Pellizer (ed.), Ulisse per sempre: miturgie omeriche e cultura mediterranea, Trieste, Editreg, 2013, pp. 3-12. 
PELLIZER Ezio, "Time and Space in Argolic Traditions: From Ocean to Europe", in A. Bierl, M. Christopoulos \& A. Papachrysostomou (eds), Time and Space in Ancient Myth, Religion and Culture, Berlin / Boston, De Gruyter, 2017, pp. 207-16.

PEREIRA Daniela F. dos Santos, O Mito de Atalanta das fontes clássicas à receção na arte ocidental, thesis, University of Coimbra, 2016. Available on <https://estudogeral.uc.pt/bitstream/ 10316/36757/1/O mito de Atalanta.pdf> (consulted September 2020).

PRELLER Ludwig, Demeter und Persephone, Hamburg, Perthes-Besser und Mauke, 1837.

PRELLER Ludwig, Griechische Mythologie ${ }^{1}, 2$ vols, Leipzig, Weidmann, 1854.

PRELLER Ludwig, rev. ROBERT Carl, Griechische Mythologie ${ }^{4}$, vol. 2.1: Landschaftliche Sagen, Berlin, Weidmann, 1920.

REID Jane D. \& ROHMAN Chris, The Oxford Guide to Classical Mythology in the Arts, 1300-1990s, 2 vols, New York / Oxford, Oxford University Press, 1993.

RODRIGUEZ ADRADOS Francisco, A History of the Greek Language: From Its Origins to the Present, Eng. tr., Leiden, Brill, 2005.

SCHEER Tanja S., Mythische Vorväter: zur Bedeutung griechischer Heroenmythen im Selbstverständnis kleinasiatischer Städte, München, Maris, 1993.

SCHIRMER Adolf, “Atalante”, in W. H. Roscher (ed.), Ausführliches Lexikon der griechischen und römischen Mythologie, vol. 1, Leipzig, Teubner, 1884, pp. 664-8.

VERNANT Jean-Pierre, Mortals and Immortals: Collected Essays, tr. F. Zeitlin, Princeton, Princeton University Press, 1991.

VIDAL-NAQUET Pierre E., “Le Chasseur noir et l'origine de l'éphébie athénienne”, in J.-P. Vernant \& P. Vidal-Naquet, La Grèce ancienne, t. 3: Rites de passage et transgression, Paris, Seuil, 1992, pp. 119-48.

WEST Martin L., The Hesiodic Catalogue of Women: Its Nature, Structure, and Origins, Oxford, Oxford University Press, 1985.

WILLIAMSON George S., The Longing for Myth in Germany: Religion and Aesthetic Culture from Romanticism to Nietzsche, Chicago, Chicago University Press, 2004.

\section{NOTES}

1. Only LIMC Atalante 81-4. "The famous footrace, popular with authors since Hesiod, was virtually ignored by Greek artists" (Boardman \& Arrigoni, 1984, 949).

2. Hunger (1988, 85-6). Exhaustive listing of pictorial art and some surprises (Granville Bantock's opera, Atalanta in Calydon of 1911, though that was in fact based on Swinburne rather than directly on antiquity): Reid \& Rohman (1993, 1, 237-40; 2, 655-8); Pereira (2016, Anexo 1), derived from Reid, but simpler to use.

3. Fowler $(2013,110)$ thinks too of an original figure that has become splintered. So did Fontenrose $(1981,176)$ : "but in truth there is only one Atalanta".

4. Bremmer in Dowden \& Livingstone (2011, ch. 28).

5. Müller $(1825,59)$.

6. Homer, Iliad, II, 653-70; Strabo, 14, 2, 6; Diodoros, 4, 58, 7. Malkin (2011, 66-70); Dowden $(1989,122)$.

7. See e.g. Finkelberg (2005, ch. 4, esp. 79-89). 
8. Assmann (1992, 75-8 and 42-5).

9. Dowden (1992, 7-8); Dowden \& Livingstone (2011, 3-4).

10. Müller $(1825,171=1844,111)$; classic expression in Max Müller $(1856,6-9$, esp. 7 for the Eocene).

11. Scholiast on Euripides, Medea, 6 .

12. Scheer (1993, passim but NB 337); Graf in Dowden \& Livingstone (2011, ch. 11).

13. Pellizer $(2013,5)$, genially, more suo, plucking out of the air a concept of Northrop Frye.

14. Williamson (2004, 146-8). The Prolegomena is available in a 1991 Italian translation under the title Prolegomeni ad una mitologia scientifica. In some ways this approach goes back to Herder, cf. Gruppe $(1921,153)$, but there is no doubt that Müller "betont erstens den lokalen Charakter des griechischen Mythos" (ibid., 154). See the English translation too (Müller, 1844, 168-9).

15. Müller $(1825,226=1844,166)$. Rather similar is Assmann's focus on myths as Fundierende Geschichten (1992, 75-6).

16. K. Dowden, in Dowden \& Livingstone (2011, ch. 3).

17. Gruppe (1921, 153-72).

18. K. Dowden, in Dowden \& Livingstone (2011, 67-70).

19. Preller (1854, vol. 2: Die Heroen).

20. Preller's months with Müller in 1832: Baumeister $(1888,561)$. Closeness of Preller's method to Müller's: Gruppe (1921, 198-9), though Baumeister (ibid.) also stresses his modification of that method through the more (romantic) nature-oriented approach of Welcker.

21. Preller $(1837,19$, n. $28 ; 1854,1,364)$. It is notable that the approach of the contemporary (and now forgotten) work of the archaeologist Eduard Gerhard, who clearly knew Müller, similarly stresses locality, though he not inappropriately pairs this with descent-groups (again maybe from Müller): he speaks of "Volksstamm und Oertlichkeit" $(1855,2,17)$. On Gerhard and the victory of Preller's handbook, see Gruppe $(1921,198)$.

22. Preller-Robert (1920, esp. vII).

23. I think of works of Angelo Brelich, Walter Burkert, Jan Bremmer, to an extent Claude Calame, Pierre Brulé, myself, and most recently Fritz Graf in Dowden \& Livingstone (2011, ch. 11).

24. This is related to C. Calame's analysis of reductive, decontextualising tendencies to which semiotic interpretations are susceptible in Dowden \& Livingstone $(2011,515)$.

25. Bettelheim (1976).

26. Dowden (1992, 58-60); much wider-ranging, Nick Allen, in Dowden \& Livingstone (2011, 34156, esp. 352-4).

27. Gruppe (1921, 161), describing the position of Müller (cf., e.g., 1825, 145-6).

28. See Müller $(1844,268)$ on migration.

29. Nilsson (1932, passim and esp. ch. 1).

30. Vidal-Naquet (1992, 144-5); Pellizer $(2011,159)$.

31. For the copulative $\dot{\alpha}-$, see Chantraine (1968, 2, s.v. " $\dot{\alpha}-:$ (et $\dot{\alpha}-)$ "). "Atalanta" as equivalent to a man: "näheliegensdste", Kretschmer (1911, 267); "égale à un homme”, Boisacq (1916, 937). For various possibilities, effectively including this one, see Schirmer $(1884,667)$; less clear in J. Escher-Bürkli, "Atalante", RE, 2, 1896, col.1890. Atalanta could be depicted with Amazonian characteristics: Barringer (1996, 49, 59-61). The term óvนı⿱㇒́veı $\propto \alpha$, applied to Amazons, is the same, effectively, as “Atalante" on this interpretation Kretschmer (1911, 267-8).

32. Pellizer (1982, 27); Vernant (1991, 199-200). Cf Barringer's summary (1996, 74-6) of the significance of Atalanta, and her liminal state.

33. To his credit not Schirmer $(1884,664)$.

34. The last note ("丷 $\lambda \lambda \omega \varsigma$ ) in $\Sigma$ Euripides, Phoenissae, 150, is related but brief.

35. $\Sigma$ Apollonius Rhodius, I, 769-73, emended by K. Wendel, Scholia in Apollonium Rhodium vetera,

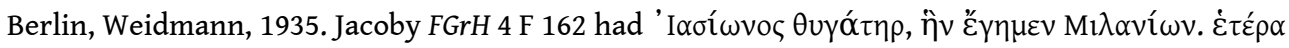

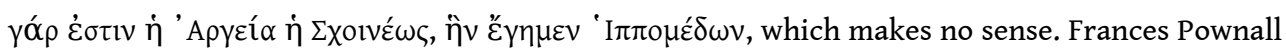


has quietly corrected it in BNJ (4 F 162). It is not clear, however, that the Scholiast's remarks derive in this sentence from Hellanikos, as Pownall remarks ad loc.

36. Cf. K. Dowden on $B N J^{2} 79 \mathrm{~F} 1$.

37. I cannot trace any reference to this passage in the collections of fragments of Euripides. Frazer's note in the Loeb suggests a reference to his Meleager (Kannicht, 2004, 554-68 = FF 51539), but nothing we know about that play allows room for Hippomenes.

38. "Schoineus": Tryphon (see next note).

39. Tryphon F 83 de Velsen = Steph. Byz. s.v. $\Sigma$ Xoıvoũ ; Müller $(1844,209)$.

40. Dowden (1989, 156-7).

41. Finkelberg (2005, ch. 4).

42. Pellizer (1986, esp. 45). It is clearly also significant that it is gold apples that are deployed as Atalanta gives way to marriage: see Faraone (1990, esp. 230-3).

43. Her rejection of marriage is so central to her character that a speaker in Euripides' Meleager who wishes never to be married may be recognised ipso facto as Atalanta speaking: Euripides, F 525 Kannicht.

44. Pausanias, VII, 19, with Dowden (1989, 169 and n. 5).

45. Dowden (1989, 202-3); Dowden, in Dowden \& Livingstone (2011, 497-9).

46. I presume these statements about where each ruled are from Hesiod, though equally I notice it is an issue for the Hypotheses of Euripides' Phrixos, where in one he is king of Thessaly and in the other of Boiotia: see Huys $(1997,319)$.

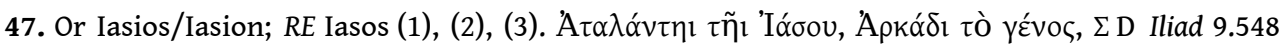
(= "Mythographus Homericus").

48. The line in question is Euripides, Phoenissae, 1162: see Jacoby on FGrH 4 F 162, and Arrigoni (2019, 74-5).

49. For the detail of sources see Gantz $(1993,335)$.

50. See Collard \& Cropp $(2008,616)$.

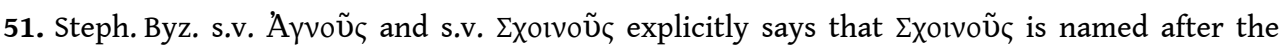
reeds that grow in its marshy ground, as well as repeating what Pausanias was told.

52. “Conflated", Boardman \& Arrigoni $(1984,940)$.

53. See further Arrigoni (2019, 73-5).

54. Gantz (1993, 337-8).

55. Vidal-Naquet $(1992,144)$; Pellizer $(1982,27)$.

56. Buxton (2010, 38-9). This view is clearly explained by Arrigoni $(2019,196)$.

57. Graf $(1985,236)$.

58. Maass (1889). To his references should be added Gallus, effectively depicting himself as Melanion on Mt Maenalus, in Vergil, Eclogues, X, 15 and 55-7.

59. Preller-Robert (1920, 93); Callimachus, Hymn to Artemis, 222-4; Apollodoros, III, 9, 2.

60. Though perhaps relics were part of Spartan policy at the time, cf. Leahy (1955).

61. Though scholars have sometimes been overeager to find hypostases, e.g. Fontenrose $(1981,177)$.

62. Theognis, 1288; Dowden (1989, 121-2); cf. also Arrigoni $(2019,79)$.

63. Apollodoros, II, 1, 3; Pausanias, II, 16, 1; Dowden (1989, 118 and 194). Pellizer (2017, 208, n. 7)

64. On which see Allen (1909, esp. 86-9).

65. Pelasgic: Iliad, II, 681; this means Thessaly, according to Strabo, VIII, 6, 5, possibly with Ephoros in the background (cf. BNJ 70 F 113). Axallkóv: Iliad, IX, 141 and 283; XIX, 115; Odyssey, III, 251; this means the Peloponnese, or maybe specially Lakonia, according to Strabo, VIII, 5, 5.

66. Allen $(1909,87)$.

67. Nikolaev (2006, esp. 100-2). Cf. the digamma in the name Ion at Kretschmer (1909, 14 and n. 2). The laryngeal is presumably hypothesised to account for the length of the i (in $\tilde{\hat{i} \varphi})$ and to restore a CVC structure. 
68. 'I $\alpha 0 \lambda$ kó $\varsigma$ in Pindar and at Odyssey, XI, 256. Kretschmer (1909, 13-14); Frisk (1960, I, 748, s.v. "I $\omega v \varepsilon \varsigma)$; also entertained by Beekes (2010, s.v. "I $\omega v \varepsilon \varsigma)$. For $-a(w)$ on names, cf. Porthaon (Hesiod, F 10.50 Most; Apollodoros, I, 7, 4; Euripides, F 515, 4 Kannicht, from the Meleagros), and, more transparent in Greek, Machaon and Alkmaon (Alkman). For -asos, cf. Pēgasos?

69. Kretschmer (1909, 9-14).

70. There is a concise and insightful discussion at Fowler $(2013,191-4)$. The topic obviously goes back to Müller (1844). Last rites: their loss of Orchomenos in $371 \mathrm{BC}$ following the Battle of Leuktra (Pausanias, IV, 27, 10).

71. Fowler $(2013,192)$.

72. Orchomenos is not a frequent name. All four instances can be fitted into a migration theory. The other two, known from single references, are in Thessaly (Diodoros, XX, 111, 1) and Euboia (near Karystos, Strabo, IX, 2, 42).

73. Dowden (1989, 57-8). RE Orchomenos (1), (4), (2). Müller (1844, e.g. 244-5).

74. Meyer (1939, esp. 896).

75. Pausanias, VIII, 5, 11-12 (without Aristodemos); Herakleides Pontikos in Diogenes Laertius, I, 94 (Aristodemos in some sense joint with Aristokrates); Aristodemos is of course the name of the Messenian king in the First Messenian War, and the adverse stories about Aristokrates in Pausanias suggest he must have been the last king. Perhaps Diogenes has misunderstood Herakleides. See also F. Hiller von Gaertringen, “Aristokrates (1)”, RE, 2 (1896), 938-9.

76. Kuhnert (1894, 2611); cf. Preller-Robert (1920, 92). Cf. also Barringer (1996, 54, excellent for the art), but with unfortunate reference to non-existent "folk-tales" at 54, n. 25. Grossardt (2001, 270-5) is altogether sceptical about the antiquity of the pairing of Atalanta and Meleager but has not envisaged merger of independent Atalanta traditions.

77. See Arrigoni (2019, 80-3) on LIMC Atalante 2 and other comparable early pots.

78. Dowden (1989, 113-5). And cf. Dowden (1992, 129-33, on "beyond", and 137 on Herakles).

79. Apollodoros, I, 9, 16; Diodoros, IV, 41, 2; 48, 5; Boardman \& Arrigoni (1984, 940).

80. Vidal-Naquet $(1992,142)$.

81. Preller-Robert $(1920,93)$.

82. It is possible that we should add a fourth location too in the light of Atalanta's wrestling match with Peleus at the funeral games for Pelias at Argos, cf. Barringer (1996, 66-70).

83. West (1985, 65-6); Gantz (1993, 167 and 182-3). Reduced to "a slight possibility" by Fowler (2013, 192), who is concerned, not unreasonably, that Minyans should be kept independent of Aiolians.

84. Müller $(1844,209)$ had already seen the comparability of the genealogical position of the two Atalantas ("sagt dasselbe, nur mit anderen Wörten").

85. For all these initiatory figures, see Dowden (1989) and Brulé (1987, e.g. 220-1).

86. Gruppe $(1921,161)$; interesting discussion by Müller $(1825,226)$.

87. Pellizer (2007), taking of course a characteristically semiotic, rather than historicising, approach to that myth.

88. List at Nikolaev $(2006,102)$.

89. Rodriguez Adrados $(2005,57)$.

90. Immerwahr (1891, 165-6, Ares cult).

91. Herodotos, I, 146.

92. Fowler $(2013,192)$.

93. Kretschmer (1911, 266); Chantraine $(1968,1089)$.

94. Burkert (1992, 37 with 175, n. 17). NB Luwians had the mina.

95. The $-n$ - is not de rigueur, to judge by the François vase LIMC Atalante 2 (ATA ATE), but in any case it is a very weak syllable close, near to a nasal vowel. Conversely, and alternatively, I do wonder whether a double -nn- might not be heard as -nt- and whether this might explain the 
frequent $-n t / n d / n t h$ - of pre-Greek, given the propensity of Luwian-type languages for that suffix. *Atalanna?

96. For Tantalos, cf. Kretschmer (1896, 204-6). For Atalanta, see Frisk (1960, I, 176), taking the view that this is an instance of a "volksteymologische Umbildung eines ungriechischen Namens"; this view is adopted by Beck (1979) and recognised by the G.R.I.M.M. Dizionario Etimologico della Mitologia Greca s.v. Cf. also Atlas (Atlant-), Akamas (Akamant-), Adamas (Adamant-), as well as the substance adamant (etymologised in Greek as "unsubduable"). More generally, Athāna (Athene) is of course a famous example of a word composed with non-Indo-European open syllables.

97. The distribution comes close to Margalit Finkleberg's "Dialect Map of Prehistoric Greece" (Finkelberg, 2005, 132).

\section{ABSTRACTS}

Atalanta provides a significant case study for the historical development of Greek myth. Myth stands in a complex relationship to history, in which the localisation of any myth plays a key role, an important lesson we learn from Otfried Müller. The Atalanta mythology, splintered into different locations, but sharing genealogical and initiatory functions, shows how population movement in the (mythopoeic) Mycenaean age resulted in Sagenwanderung involving Boiotia, Arkadia and Aitolian Kalydon. There may also be traces of pre-Greek elements in the proper names of the mythology.

Atalante nous offre une étude de cas importante pour le développement historique de la mythologie grecque. Le mythe entretient une relation complexe avec l'histoire, dans laquelle la localisation de chaque mythe joue un rôle clé, comme nous l'a appris en premier Otfried Müller. Le mythe d'Atalante qui se déroule en différents lieux, mais qui partage certaines fonctions généalogiques et initiatiques, montre comment les mouvements des peuples à l'époque (mythopéique) mycénienne ont abouti à un Sagenwanderung impliquant la Béotie, l'Arcadie et Calydon, en Étolie. On peut également trouver des traces d'éléments pré-grecs dans les noms propres de la mythologie.

\section{INDEX}

Mots-clés: Atalante, Calydon (sanglier), Orchomène, lieu (dans la mythologie), initiation, Sagenwanderung (mobilité des mythes)

Keywords: Atalanta, Kalydonian boar, Orchomenos, localisation (in myth), initiation, Sagenwanderung (myths on the move)

\section{AUTHOR}

\section{KEN DOWDEN}

University of Birmingham

k.dowden@bham.ac.uk 